\title{
Nitrogen removal performance and operation strategy of anammox process under temperature shock
}

\author{
Weiqiang Zhu $\cdot$ Jin Li $\mathbb{1} \cdot$ Huiyu Dong $\cdot$ Dan Wang $\cdot$ Peiyu Zhang
}

Received: 3 February 2017 / Accepted: 2 May 2017 / Published online: 5 May 2017

(C) Springer Science+Business Media Dordrecht 2017

\begin{abstract}
Sequencing batch reactors were used to study anaerobic ammonium oxidation (anammox) process under temperature shock. Both long-term $\left(15-35^{\circ} \mathrm{C}\right)$ and short-term $\left(10-50{ }^{\circ} \mathrm{C}\right)$ temperature effects on nitrogen removal performance were performed. In reactor operation test, the results indicated that ammonium removal rate decreased from $0.35 \mathrm{~kg} /$ $\left(\mathrm{m}^{3}\right.$ day) gradually to $0.059 \mathrm{~kg} /\left(\mathrm{m}^{3}\right.$ day $)$ when temperature dropped from 35 to $15^{\circ} \mathrm{C}$. Although bacteria morphology was not modified, sludge settling velocity decreased with decreasing temperature. In batch test, apparent activation energy $\left(E_{a}\right)$ increased with decreasing temperature, which suggested the activity decrease of anaerobic ammonium oxidizing bacteria (AAOB). Low temperature inhibited AAOB and weakened nitrogen removal performance. The cardinal temperature model with inflection was first used to describe temperature effect on anammox process.
\end{abstract}

W. Zhu $\cdot$ J. Li $(\varangle) \cdot$ P. Zhang

School of Environmental Science and Engineering, Qingdao University, Qingdao 266071, China

e-mail: 1jin0532@126.com

H. Dong

Key Laboratory of Drinking Water Science and Technology, Research Center for Eco-environmental Sciences, University of Chinese Academy of Sciences, Chinese Academy of Sciences, Beijing 100085, China

D. Wang

National Marine Environmental Forecasting Center, State Oceanic Administration, Beijing 100081, China
Simulated results revealed that anammox reaction could occur at $10.52-50.15^{\circ} \mathrm{C}$ with maximum specific anammox activity of $0.50 \mathrm{~kg} /(\mathrm{kg}$ day $)$ at $36.72{ }^{\circ} \mathrm{C}$. The cold acclimatization of AAOB could be achieved and glycine betaine could slightly improve nitrogen removal performance at low temperature.

Keywords Anammox - Temperature shock . Kinetics $\cdot$ Apparent activation energy $\left(\mathrm{E}_{\mathrm{a}}\right) \cdot$ Operation strategy $\cdot$ Glycine betaine

\section{Introduction}

With unique cell structure and ability to remove ammonium and nitrite simultaneously, anaerobic ammonium oxidation bacteria (AAOB) have broadened biological nitrogen cycle process (Schleper 2008). However, as an efficient and cost-effective technology to treat wastewater, anaerobic ammonium oxidation (anammox) still faced some problems like low temperature. Most of full-scale anammox reactors reported in literatures were operated at a temperature exceeding $25^{\circ} \mathrm{C}$ (Dosta et al. 2008; van der Star et al. 2007; Zhang et al. 2016). As a result, wastewater must be heated to required temperature. This increased treatment cost undoubtedly and weakened its commercial application.

As one of the most important factors, temperature affected activity and growth of AAOB. Although anammox process could occur in a wide range of temperatures $\left(6-43{ }^{\circ} \mathrm{C}\right)$ (Kartal et al. 2010), the 
optimal temperature for $\mathrm{AAOB}$ was acquired not the same, e.g., $40{ }^{\circ} \mathrm{C}$ acquired by Jetten et al. (1998), $35-40{ }^{\circ} \mathrm{C}$ acquired by Dosta et al. (2008) and $37{ }^{\circ} \mathrm{C}$ acquired by Isaka et al. (2008). Still, anammox process would perform very well at 30-40 ${ }^{\circ} \mathrm{C}$ (Egli et al. 2001; Strous et al. 1999), in which anammox activity would not be affected by temperature. However, the temperature of wastewater was generally below $25{ }^{\circ} \mathrm{C}$ and varied with outer surroundings (de Graaff et al. 2011; Guo et al. 2015). This was much lower than optimum temperature of AAOB. As a result, the main challenge to apply anammox process widely was to achieve high nitrogen removal performance at low temperature.

Recently, AAOB was identified in some harsh environments, such as deep-sea hydrothermal vents (Byrne et al. 2009) and Arctic sea ice (Rysgaard and Glud 2004). This proved that AAOB had activity among a wide temperature range. Although good nitrogen removal performance has been reported under moderately low temperatures of $20-12{ }^{\circ} \mathrm{C}$ (Isaka et al. 2007), significant drop of specific anammox activity (SAA) was found (Dosta et al. 2008; Lotti et al. 2014a, b).

The efficient and stable anammox process at low temperature would extend its application potential to treat municipal sewage and other industrial wastewater (Lotti et al. 2014a, b). Therefore, it was significant to study operation strategy at low temperature. Compatible solute was defined as small and soluble organic molecule which could occur at high intracellular concentration without hindering normal cellular metabolism (Brown 1976). As an ordinary compatible solute, glycine betaine was typically used to reduce toxicity resulting from high salinity (Vyrides and Stuckey 2009). As a kind of cryoprotectant, glycine betaine also had protective effect to against freeze thaw treatment of cell and enzyme (de Costa et al. 1998). Vyrides et al. (2010) indicated that $1 \mathrm{mM}$ glycine betaine could be beneficial anaerobic biomass performance $\left(\mathrm{CH}_{4}\right.$ production) at $20{ }^{\circ} \mathrm{C}$. Cleland et al. (2004) also found that glycine betaine was an effective cryoprotectant for prokaryotic organism through holding cell membrane fluidity and protecting cellular protein from cold aggregation. However, addition of glycine betaine on nitrogen removal performance of anammox under low temperature was studied little.

In this work, short-term effect of temperature on anammox was studied through batch test while longterm effect of temperature on anammox process was evaluated by continuous-flow test. Besides, four kinetic models were used to simulate the effect resulting from temperature shock. Some of them were first used in anammox process. In addition, operation strategy to improve anammox activity under low temperature was also investigated.

\section{Materials and methods}

Inoculation and synthetic wastewater

The seeding sludge was inoculated from a lab-scale sequencing batch reactor (SBR) operated over 1 year at $35{ }^{\circ} \mathrm{C}$. The digital and microscopic pictures of the sludge were shown in Fig. 1. Influent $\mathrm{NH}_{4}{ }^{+}-\mathrm{N}$ and $\mathrm{NO}_{2}{ }^{-}-\mathrm{N}$ concentrations of lab-scale SBR were 80 and $105 \mathrm{mg} / \mathrm{L}$, respectively. Both removal efficiencies were more than $99 \%$. The sludge was bright red with good settling property. The mixed liquid suspended solid (MLSS) concentration inoculated in SBR was $1.61 \mathrm{~g} / \mathrm{L}$. The diameter of granular sludge was $0.5-5.0 \mathrm{~mm}$ with a mean value of $1.72 \mathrm{~mm}$. Synthetic wastewater was used in this work and its composition was presented in Table 1.

\section{Long-term effect of temperature}

Three SBRs (R1, R2 and R3) were operated in parallel during long-term operation. The working volume of each reactor was $1.5 \mathrm{~L}$. Each reactor was inoculated with $1 \mathrm{~L}$ anammox sludge. All reactors were covered completely with aluminum caps to avoid the growth of photosynthetic microorganisms. The produced gas was discharged via porthole on the top of the reactor. The complete mixture inside the reactor was achieved through mechanical stirrer with rotating speed of $100 \mathrm{rpm} . \mathrm{N}_{2}(99.99 \%)$ was purged into influent in order to maintain anaerobic condition. Each reactor was sparged by $\mathrm{N}_{2}$ for 10 min before the sludge was inoculated into it. The initial $\mathrm{pH}$ was 7.5 by adding $1.0 \mathrm{~mol} / \mathrm{L}$ hydrochloric acid or sodium hydroxide. The ammonium loading rate (ALR) and nitrite loading rate (NLR) were kept at $0.36 \pm 0.04 \mathrm{~kg} /\left(\mathrm{m}^{3}\right.$ day) and $0.44 \pm 0.05 \mathrm{~kg} /\left(\mathrm{m}^{3}\right.$ day $)$, respectively.

Temperature of the reactor decreased gradually from 35 to $15{ }^{\circ} \mathrm{C}\left(35,30,25,20\right.$ and $\left.15^{\circ} \mathrm{C}\right)$ during the operation. The reactors were operated at least 9 days at each temperature. Hereafter, R1 was analyzed for recovery performance of anammox process. R2 was 

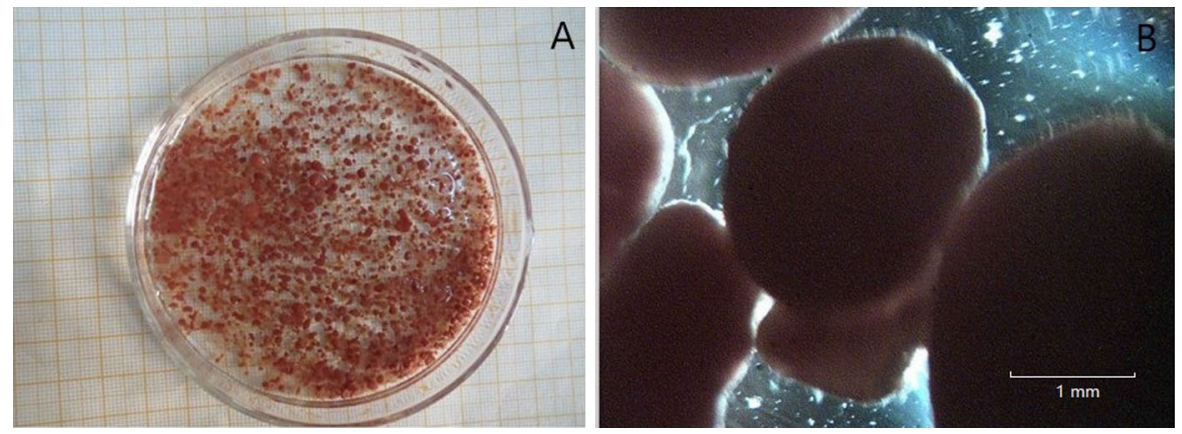

Fig. 1 Image of inoculated granular sludge

Table 1 Composition of synthetic wastewater

\begin{tabular}{llll}
\hline Compound & Concentration $(\mathrm{g} / \mathrm{L})$ & Compound & Concentration $(\mathrm{g} / \mathrm{L})$ \\
\hline $\mathrm{KH}_{2} \mathrm{PO}_{4}$ & 0.028 & $\mathrm{NH}_{4} \mathrm{Cl}$ & 0.080 \\
$\mathrm{CaCl}_{2}$ & 0.14 & $\mathrm{NaNO}_{2}$ & 0.105 \\
$\mathrm{KHCO}_{3}$ & 2.0 & Trace element solution I & $1.1 \mathrm{~mL} / \mathrm{L}$ \\
$\mathrm{MgSO}_{4} \cdot 7 \mathrm{H}_{2} \mathrm{O}$ & 0.2 & Trace element solution II & $1.1 \mathrm{~mL} / \mathrm{L}$ \\
\hline
\end{tabular}

Trace element solution I: EDTA $5 \mathrm{~g} / \mathrm{L}, \mathrm{FeSO}_{4} \cdot 7 \mathrm{H}_{2} 05 \mathrm{~g} / \mathrm{L}$

Trace element solution II: EDTA $15 \mathrm{~g} / \mathrm{L}, \mathrm{H}_{3} \mathrm{BO}_{3} 0.011 \mathrm{~g} / \mathrm{L}, \mathrm{MnCl}_{2} \cdot 4 \mathrm{H}_{2} \mathrm{O} 0.99 \mathrm{~g} / \mathrm{L}, \mathrm{CuSO}_{4} \cdot 5 \mathrm{H}_{2} \mathrm{O} 0.25 \mathrm{~g} / \mathrm{L}, \mathrm{ZnSO}_{4} \cdot 7 \mathrm{H}_{2} \mathrm{O} 0.43 \mathrm{~g} / \mathrm{L}$, $\mathrm{NiCl}_{2} \cdot 6 \mathrm{H}_{2} \mathrm{O} 0.19 \mathrm{~g} / \mathrm{L},\left(\mathrm{NH}_{4}\right)_{6} \mathrm{Mo}_{7} \mathrm{O}_{24} \cdot 4 \mathrm{H}_{2} \mathrm{O} 0.16 \mathrm{~g} / \mathrm{L}, \mathrm{CoCl}_{2} \cdot 6 \mathrm{H}_{2} \mathrm{O} 0.24 \mathrm{~g} / \mathrm{L}, \mathrm{Na}_{2} \mathrm{SeO}_{3} \cdot 5 \mathrm{H}_{2} \mathrm{O} 0.1596 \mathrm{~g} / \mathrm{L}$

continuously operated at $15{ }^{\circ} \mathrm{C}$ for more than 50 cycles. R3 was carried out at $20^{\circ} \mathrm{C}$ to analyze the effect of glycine betaine under low temperature.

\section{Short-term effect of temperature}

Batch tests between 15 and $50{ }^{\circ} \mathrm{C}(15,20,25,30,35$, 40,45 and $50^{\circ} \mathrm{C}$ ) were carried out to investigate the short-term effect of temperature on SAA. Completely closed vials with a liquid volume of $100 \mathrm{~mL}$ were used and influent $\mathrm{NH}_{4}{ }^{+}-\mathrm{N}$ and $\mathrm{NO}_{2}{ }^{-}-\mathrm{N}$ concentrations were $80 \mathrm{mg} / \mathrm{L}$ and $105 \mathrm{mg} / \mathrm{L}$, respectively, with $\mathrm{NH}_{4} \mathrm{Cl}$ and $\mathrm{NaNO}_{2}$ as the sources. At the initial of the test, the sludge concentration was $1.61 \mathrm{~g} / \mathrm{L}$. Influent $\mathrm{pH}$ was set at 7.5 and $\mathrm{N}_{2}$ was purged into reactors to remove $\mathrm{O}_{2} \cdot \mathrm{NH}_{4}{ }^{+}-\mathrm{N}$ and $\mathrm{NO}_{2}{ }^{-}-\mathrm{N}$ were determined at regular intervals, and SAA was calculated by the ratio of maximal substrate consumption rate to sludge concentration (Qiao et al. 2014).

Kinetic analysis

Arrhenius model (Eq. 1) has been widely used to describe the effect of temperature on biological activity, and the apparent activation energy $\left(E_{a}\right)$ was calculated through the slope of the regression line according to the modified Arrhenius model (Eq. 2) (Isaka et al. 2008; Jin et al. 2013). However, the Arrhenius model had the drawback that it could not model the decrease of SAA at the temperature above optimal one (Wang and Wan 2009). In order to overcome this limitation, the Hinshelwood model (Eq. 3) (Rosso et al. 1993) which was dependent on the Arrhenius model was put forward to simulate the effect of temperature on anammox activity.

$\mu=A \exp \left(-\frac{E_{a}}{R T}\right)$

$\ln \mu=-\frac{E_{a}}{R T}+\ln \mathrm{A}$

$\mu=\mathrm{k}_{1} \exp \left(\frac{-E_{a}}{R \times T}\right)-k_{2} \exp \left(\frac{-E_{b}}{R \times T}\right)$

where $\mu$ is SAA at certain temperature, $\mathrm{kgNH}_{4}{ }^{+}-\mathrm{N} /$ (kgMLSS day); $\mathrm{E}_{\mathrm{a}}$ is apparent activation energy, $\mathrm{kJ} / \mathrm{mol} ; \mathrm{E}_{\mathrm{b}}$ is high-temperature denaturation, $\mathrm{kJ} / \mathrm{mol}$; $\mathrm{R}$ is ideal gas constant, $8.314 \mathrm{~J} /(\mathrm{kg} \mathrm{K}) ; \mathrm{T}$ is 
thermodynamic temperature, $\mathrm{K} ; \mathrm{k}_{1}, \mathrm{k}_{2}$ are frequency factors without biological basis; and A refers to Arrhenius constant.

The Ratkowsky model (Eq. 4) (Ratkowsky et al. 1982) and the Zwietering model (Eq. 5) (Zwietering et al. 1991) were used to simulate the effect of temperature on bacterial growth. The formations of both models were quite similar. In addition, the cardinal temperature model with inflection (CTMI) was developed empirically (Eq. 6) (Rosso et al. 1993). It revealed that the growth rate changed as a function of cardinal temperature parameter. To our knowledge, this was the first time that CTMI was used in anammox process. In order to describe the effect of temperature on anammox activity throughout the entire bio-kinetic temperature range precisely, three models were analyzed.

$$
\begin{aligned}
& \mu=\left[\mathrm{A}\left(\mathrm{T}-\mathrm{T}_{\text {min }}\right)\right]^{2}\left\{1-\exp \left[\mathrm{B}\left(\mathrm{T}-\mathrm{T}_{\max }\right)\right]\right\}^{2} \\
& \mu=\left[\mathrm{A}\left(\mathrm{T}-\mathrm{T}_{\text {min }}\right)\right]^{2}\left\{1-\exp \left[\mathrm{B}\left(\mathrm{T}-\mathrm{T}_{\text {max }}\right)\right]\right\}
\end{aligned}
$$

methods described by Tang et al. (2011). Sludge concentration was measured after filtering the washed samples through $0.45 \mu \mathrm{m}$ membrane filter and drying at $105{ }^{\circ} \mathrm{C}$ to constant weight. The size of granular sludge was performed according to the methods described by Tang et al. (2011). The measure of settling velocity was based on the methods of Mu et al. (2008). Each data point presented in present research was the average of three replicates, and standard deviation was lower than $10 \%$ of mean value.

\section{Results and discussion}

Long-term temperature effect on anammox process

\section{Nitrogen removal performance}

The concentrations of three nitrogen species in influent and effluent at different temperatures are

$\mu=\operatorname{Sup}\left\{0.0, \frac{\mu_{\mathrm{opt}}\left(\mathrm{T}-\mathrm{T}_{\mathrm{max}}\right)\left(\mathrm{T}-\mathrm{T}_{\min }\right)^{2}}{\left(\mathrm{~T}_{\mathrm{opt}}-\mathrm{T}_{\min }\right)\left[\left(\mathrm{T}_{\mathrm{opt}}-\mathrm{T}_{\mathrm{min}}\right)\left(\mathrm{T}-\mathrm{T}_{\mathrm{opt}}\right)-\left(\mathrm{T}_{\mathrm{opt}}-\mathrm{T}_{\mathrm{max}}\right)\left(\mathrm{T}_{\mathrm{opt}}+\mathrm{T}_{\min }-2 \mathrm{~T}\right)\right]}\right\}$

where $T_{\min }$ and $\mathrm{T}_{\max }$ are the minimum and maximum temperature at which nitrogen removal performance is observed, ${ }^{\circ} \mathrm{C} ; \mathrm{T}_{\mathrm{opt}}$ is the temperature at which the maximum SAA equals its optimum value $\mu_{\text {opt }}$; and $\mathrm{A}$, $\mathrm{B}$ are two parameters without biological basis.

Analytical methods

The supernatants were analyzed for $\mathrm{NH}_{4}{ }^{+}-\mathrm{N}, \mathrm{NO}_{2}{ }^{-}-\mathrm{N}$ and $\mathrm{NO}_{3}{ }^{-}-\mathrm{N}$ concentrations according to the standard methods (APHA 1998). Temperature and $\mathrm{pH}$ were measured by the WTW 340i/SET pH/Oxi portable multi parameter measuring meter. Microscopic images were taken with the light microscope (Olympus, CX31) and photos were taken with the digital camera (Canon, IXUS 500 HS). The morphological properties of the granules were observed by scanning electron microscopy (SEM) according to the presented in Fig. 2a. When temperature decreased to $30{ }^{\circ} \mathrm{C}$, three nitrogen species in effluent varied little. At $25{ }^{\circ} \mathrm{C}$, effluent ammonium and nitrite increased to $3 \pm 1$ and $5 \pm 1.5 \mathrm{mg} / \mathrm{L}$, respectively, and then both increased with reduction of temperature. Effluent ammonium and nitrite increased to $80.2 \pm 2$ and $106.1 \pm 2.2 \mathrm{mg} / \mathrm{L}$, respectively, when temperature was $15^{\circ} \mathrm{C}$. The sharp increase of effluent ammonium and nitrite indicated the deterioration of anammox process. As presented in Fig. 2b, nitrogen removal efficiencies decreased with dropping temperature. Under low temperature, nitrite could not be completely removed through anammox reaction and it could accumulate in the reactor. Nitrite was an inhibitory factor for anammox process (Jung et al. 2007). As a result, poor anammox performance at low temperature could be partly attributed to nitrite accumulation. In addition, effluent nitrate decreased 

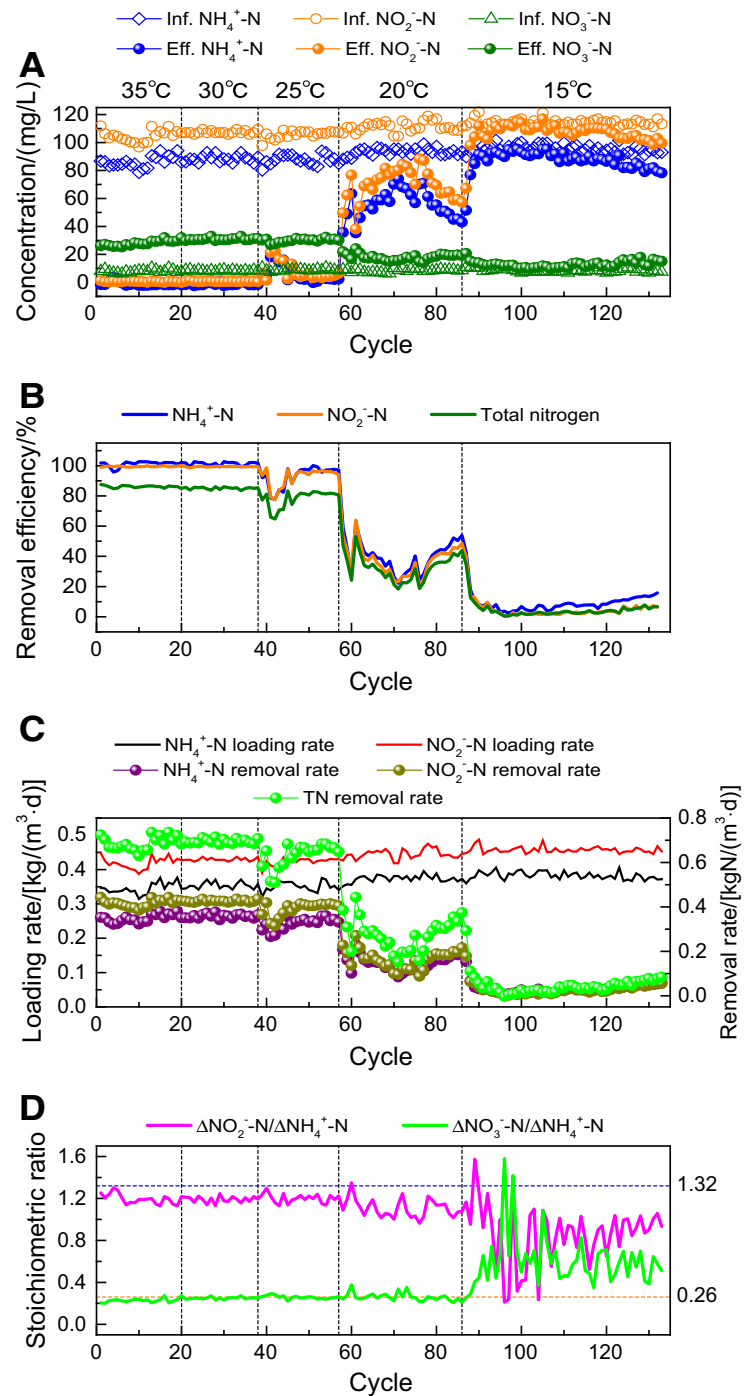

Fig. 2 Performance of Anammox process with different temperatures: a concentrations of three nitrogen species in influent and effluent; b nitrogen removal efficiency; c loading and removal rates of ammonium and nitrite; $\mathbf{d}$ stoichiometric ratio

with dropping temperature, and only small amount of nitrate was produced at $15{ }^{\circ} \mathrm{C}$.

Nitrogen removal rates with temperature are presented in Fig. 2c. Ammonium removal rate (ARR) was slightly affected when temperature was not lower than $25^{\circ} \mathrm{C}$. ARR was about $0.35 \mathrm{~kg} /\left(\mathrm{m}^{3}\right.$ day $)$ at $35{ }^{\circ} \mathrm{C}$. However, ARR was only around $0.059 \mathrm{~kg} /$ $\left(\mathrm{m}^{3}\right.$ day) when temperature was $15^{\circ} \mathrm{C}$. In terms of nitrite removal rate (NRR) and total nitrogen removal rate (TNRR), they were 0.44 and $0.70 \mathrm{~kg} /\left(\mathrm{m}^{3}\right.$ day) at $35{ }^{\circ} \mathrm{C}$, respectively. Then both decreased with dropping temperature. When temperature was $15^{\circ} \mathrm{C}$, they were around 0.029 and $0.058 \mathrm{~kg} /\left(\mathrm{m}^{3}\right.$ day), respectively. The poor nitrogen removal performance could be attributed to adverse effect resulting from low temperature on enzyme activity and mass transfer rate (Xing et al. 2015). In addition, substrate affinity of AAOB decreased under low temperature (Guo et al. 2015).

The relationship between TNRR and temperature was simulated by the modified Logistic model (Wang and Wan 2009), as shown in Fig. 3. The correlation coefficient $\left(\mathrm{R}^{2}\right)$ acquired was 0.9942 , which suggest good appropriateness to describe nitrogen removal performance. Besides, there was little variation among $25-35{ }^{\circ} \mathrm{C}$. TNRR approached $0.71 \mathrm{~kg} /\left(\mathrm{m}^{3}\right.$ day $)$ at $35{ }^{\circ} \mathrm{C}$. Then it decreased sharply with dropping temperature, and arrived at $0.055 \mathrm{~kg} /\left(\mathrm{m}^{3}\right.$ day) under $15{ }^{\circ} \mathrm{C}$. Evaluation and validation of the modified Logistic model indicated that the predicted values were in line with experimental data. The modified Logistic model was recommended to simulate and analyze the TNRR under different temperatures.

Stoichiometric ratio was the calculation of quantitative relationships between reactant and product, which was an important indicator to evaluate reaction proceeding (Du et al. 2016). As a result, the stoichiometric ratio is analyzed and presented in Fig. $2 \mathrm{~d}$. At high temperature $\left(25-35^{\circ} \mathrm{C}\right), \Delta \mathrm{NO}_{2}{ }^{-}-\mathrm{N} / \Delta \mathrm{NH}_{4}{ }^{+}-\mathrm{N}$ and $\Delta \mathrm{NO}_{3}{ }^{-}-\mathrm{N} / \Delta \mathrm{NH}_{4}{ }^{+}-\mathrm{N}$ were both stabilized at around 1.2 and 0.25 , respectively. Then, $\Delta \mathrm{NO}_{2}{ }^{-}-\mathrm{N} /$ $\Delta \mathrm{NH}_{4}{ }^{+}-\mathrm{N}$ decreased and $\Delta \mathrm{NO}_{3}{ }^{-}-\mathrm{N} / \Delta \mathrm{NH}_{4}{ }^{+}-\mathrm{N}$ increased. The transformation of stoichiometric ratios

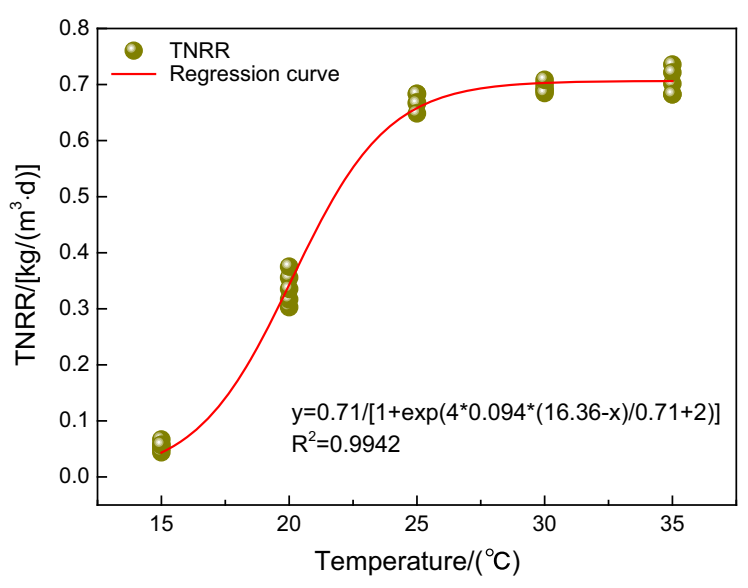

Fig. 3 Regression curve between TNRR and temperature simulated by the modified Logistic model 
could be related to change of AAOB metabolism in response to change of external environment (Kartal et al. 2007). The theoretical values of $\Delta \mathrm{NO}_{2}{ }^{-}-\mathrm{N} /$ $\Delta \mathrm{NH}_{4}{ }^{+}-\mathrm{N}$ and $\Delta \mathrm{NO}_{3}{ }^{-}{ }^{-} \mathrm{N} / \Delta \mathrm{NH}_{4}{ }^{+}{ }_{-} \mathrm{N}$ for anammox process were calculated to be 1.32 and 0.26 , respectively (Strous et al. 1998). However, both deviated from theoretical values greatly when temperature was $15{ }^{\circ} \mathrm{C}$. The decrease of $\Delta \mathrm{NO}_{2}{ }^{-}-\mathrm{N} / \Delta \mathrm{NH}_{4}{ }^{+}-\mathrm{N}$ were consistent with previously reports (Dalsgaard and Thamdrup 2002; Dosta et al. 2008). Ammonification of organic matter resulting from cell decay or lysis might occur in anammox process. This was also similar with Guo et al. (2015) that the lower value of $\Delta \mathrm{NO}_{2}{ }^{-}-\mathrm{N} / \Delta \mathrm{NH}_{4}{ }^{+}-\mathrm{N}$ might be resulting from denitrification. In addition, $\Delta \mathrm{NO}_{3}{ }^{-}-\mathrm{N} / \Delta \mathrm{NH}_{4}{ }^{+}-\mathrm{N}$ increased at $15{ }^{\circ} \mathrm{C}$ agreed with Ma et al. (2013) and Jin et al. (2013) that there might be other reaction devoting to nitrate production.

After 134 cycles' operation, the operational temperature of R1 was directly restored to $35{ }^{\circ} \mathrm{C}$. TNRR recovered to $0.70 \mathrm{~kg} /\left(\mathrm{m}^{3}\right.$ day) only after five cycles (data not shown). This agreed with Isaka et al. (2008) and Kawagoshi et al. (2012) that anammox activity would recover immediately when temperature was back to previous value. However, Dosta et al. (2008) found an irreversible loss of activity at $15{ }^{\circ} \mathrm{C}$. The difference might result from varied nitrogen loading rate and duration time. In addition, sludge floating was observed in recovery period. This might be attributed to the trapping of $\mathrm{N}_{2}$ bubbles (Quan et al. 2011). The floating sludge had poor settleability which led to sludge loss.

\section{Biomass characteristics}

Sludge settling velocity is a key factor in anammox process which was associated with wash-out of biomass. Granular sludge taken from three reactors was determined settling velocity at different temperatures and the results are presented in Fig. 4. The settling velocity was $2.15 \mathrm{~cm} / \mathrm{s}$ at $35^{\circ} \mathrm{C}$, and then it decreased with dropping temperature. When temperature was $15^{\circ} \mathrm{C}$, the settling velocity was only $1.78 \mathrm{~cm} / \mathrm{s}$. The results indicated that settling velocity of anammox sludge was positively related to temperature at the range of $15-35{ }^{\circ} \mathrm{C}$. The poor settleability suggested high biomass loss, which led to poorer performance of anammox process. This agreed with Guo et al. (2015) that bad settleability would

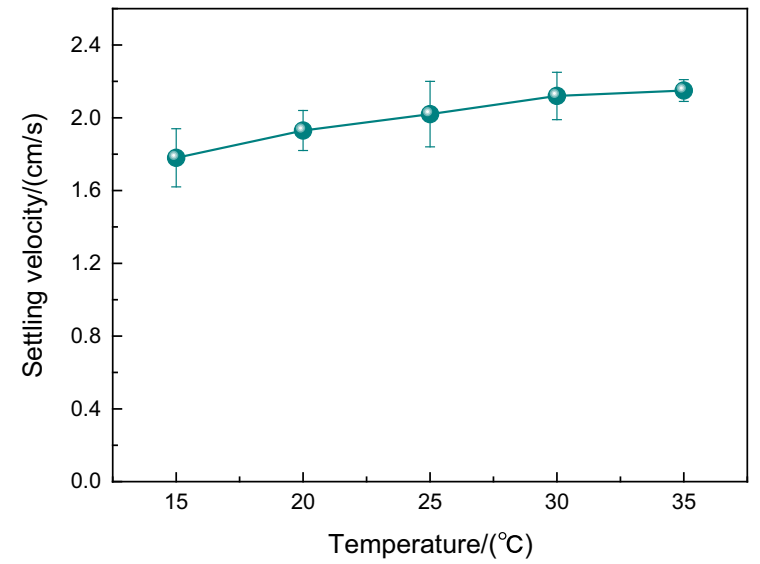

Fig. 4 Sludge settling velocity at different temperatures

contribute to poor performance of anammox system. Winkler et al. (2012) revealed that when temperature decreased from 40 to $5{ }^{\circ} \mathrm{C}$, settling velocity decreased $50 \%$. Low temperature increased the viscosity and density of wastewater (Jin et al. 2013; Winkler et al. 2012), which would inhibit the movement of biomass. As a result, low temperature had a significant effect on sludge settleability.

SBRs were inoculated with granular anammox biomass and granular sludge was kept throughout the whole period of operation. SEM images presented in Fig. 5 were acquired at 35 and $15{ }^{\circ} \mathrm{C}$. The bacteria at both temperatures were round and had the smooth surface. The morphology of bacteria did not change when temperature decreased from 35 to $15{ }^{\circ} \mathrm{C}$. This agreed with Ma et al. (2013) that anammox biomass did not change when temperature decreased from 30 to $16{ }^{\circ} \mathrm{C}$. Low temperature had little effect on bacteria morphology.

Short-term temperature effect on SAA

\section{Batch test}

Short-term effect of temperature on SAA was performed by batch test at temperature range of $10-50{ }^{\circ} \mathrm{C}$. Figure 6 indicated that there was no biomass activity when temperature was $10{ }^{\circ} \mathrm{C}$. This did not agree with Hendrickx et al. (2014) that SAA was $0.044 \mathrm{~kg} /\left(\mathrm{kg}\right.$ day) at $10{ }^{\circ} \mathrm{C}$. SAA increased when temperature increased from 10 to $35^{\circ} \mathrm{C}$. Then it decreased with further enhancement of temperature. These results were similar with previously studies 

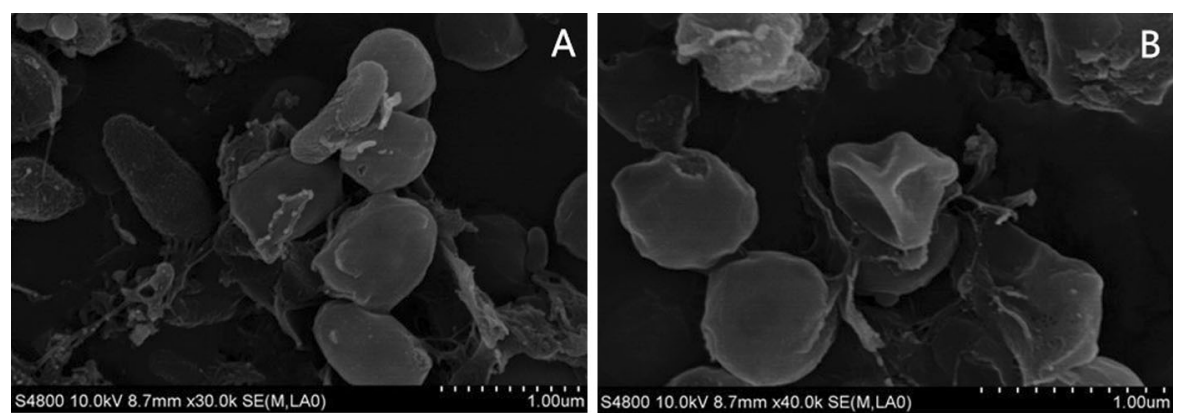

Fig. 5 SEM observation of granular sludge: a sludge withdrawn at $35{ }^{\circ} \mathrm{C}$; b sludge withdrawn at $15{ }^{\circ} \mathrm{C}$

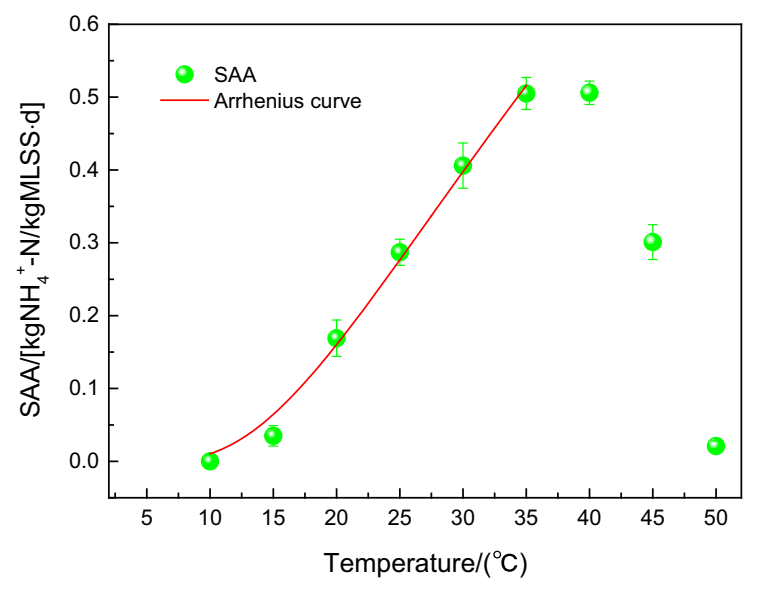

Fig. 6 Microbial activity measured at different temperatures

(Dosta et al. 2008; Isaka et al. 2008; Lotti et al. $2014 \mathrm{a}, \mathrm{b})$. As a result, inhibition on SAA would occur at extreme temperature (lower than $25^{\circ} \mathrm{C}$ and higher than $40{ }^{\circ} \mathrm{C}$ ). Anammox activity observed at $50{ }^{\circ} \mathrm{C}$ was $0.021 \mathrm{~kg} /(\mathrm{kg}$ day $)$, which was higher than previous reports (Egli et al. 2001; Dosta et al. 2008). Different anammox biomass and nitrogen loading rate might devote to the discrepancy. Besides, biomass lysis might occur at high temperature, which would be another explanation for SAA decrease (Dosta et al. 2008).

$E_{a}$ indicated necessary energy that substrate changed from normal state to active state. It was determined graphically by taking natural logarithm of the Arrhenius model (Eq. 2). As shown in Fig. 7a, the values of $E_{a}$ were calculated for each temperature intervals. The results showed that $\mathrm{E}_{\mathrm{a}}$ increased with decreasing temperature, which suggested the decrease of AAOB activity. This agreed with Lotti et al. (2015) that lower temperature would result in a sharp increase of $\mathrm{E}_{\mathrm{a}}$, and SAA seemed to decrease more on a $5{ }^{\circ} \mathrm{C}$ temperature descent. During wastewater treatment process, temperature coefficient $(\theta)$ was usually preferred (Lotti et al. 2015). The results revealed that $\theta$ also increased with decreasing temperature. As a result, low temperature inhibited anammox process, and occurrence of anammox reaction became much more difficult.

Based on the findings above, temperature effect on SAA could be described by a single $\mathrm{E}_{\mathrm{a}}$ (presented in Fig. 7b). The low value of correlation coefficent $\left(\mathrm{R}^{2}=0.93\right)$ of linear regression indicated that a single $\mathrm{E}_{\mathrm{a}}$ could not demonstrate temperature inhibition satisfactorily. As a result, two Arrhenius regression lines of data were plotted. The high correlation coefficent $\left(R^{2}>0.98\right)$ of each regression line suggested good simulation. From these plots, $\mathrm{E}_{\mathrm{a}}$ of AAOB could be calculated by the Arrhenius equation for each temperature range. Different slope of the regression line for different temperature interval (35-25 and $25-15{ }^{\circ} \mathrm{C}$ ) was acquired. Each slope deviated from regression linear which was plotted in the whole temperature interval $\left(35-15^{\circ} \mathrm{C}\right)$. The smaller value of $\mathrm{E}_{\mathrm{a}}(69.5 \mathrm{~kJ} / \mathrm{mol})$ in temperature interval $25-15^{\circ} \mathrm{C}$ indicated lower biomass activity at low temperature.

According to Fig. 7b, there is a flexion point existing between two regression lines at $20-30{ }^{\circ} \mathrm{C}$. Two rate-determining enzymes with different optimum temperatures might exist in AAOB (Isaka et al. 2008). In addition, there might be other types of microorganisms in anammox system, and their relative activities were not the same as AAOB. A shift of relative activity during different microorganisms was possible in reactors. When external temperature decreased, anammox biomass was affected, but other bacteria activity with lower optimum temperature was enhanced (Hendrickx et al. 2012). 

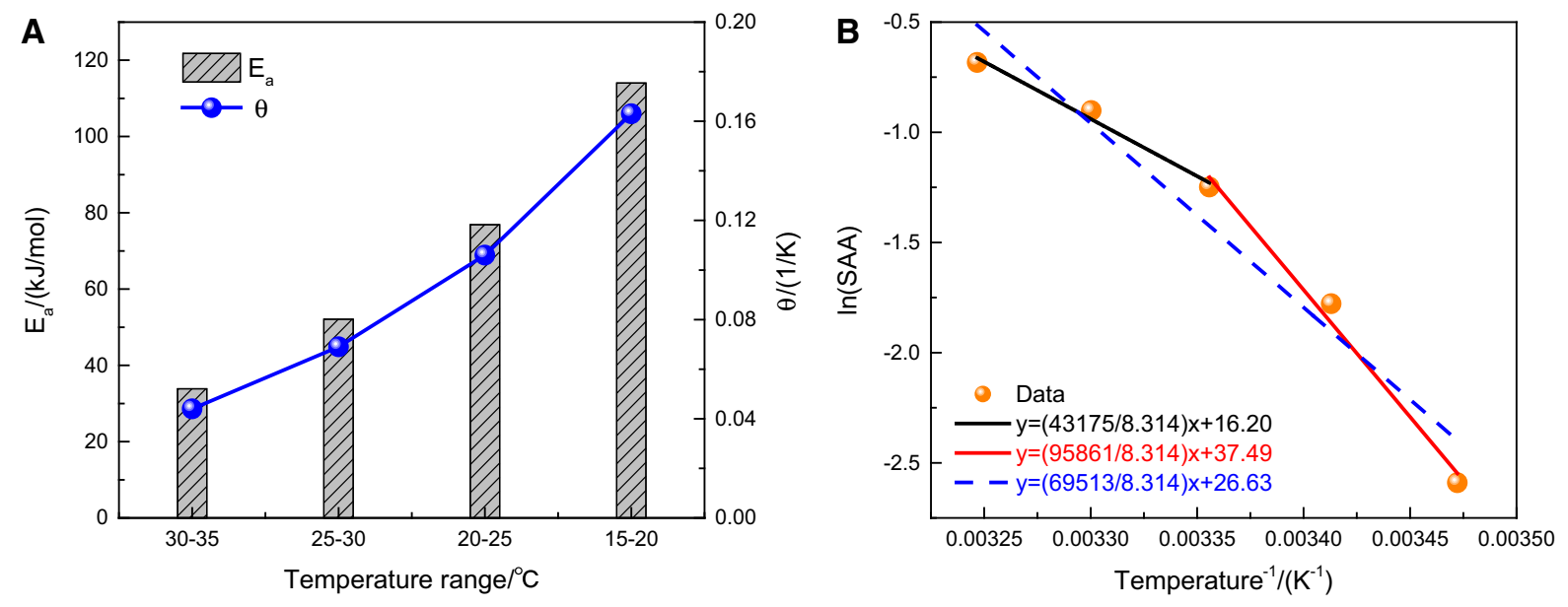

Fig. 7 a $E_{a}$ and $\theta$ plotted by Arrhenius equation; $\mathbf{b} \mathrm{E}_{\mathrm{a}}$ relative to two temperature intervals

Table 2 Comparison of Ea in this work and previous studies

\begin{tabular}{lllll}
\hline Temperature interval $\left({ }^{\circ} \mathrm{C}\right)$ & Optimum temperature $\left({ }^{\circ} \mathrm{C}\right)$ & Biomass type & $\mathrm{E}_{\mathrm{a}}(\mathrm{kJ} / \mathrm{mol})$ & Reference \\
\hline $6-22$ & 37 & Entrapped biomass & 94 & Isaka et al. (2008) \\
$22-28$ & 37 & Entrapped biomass & 93 & Isaka et al. (2008) \\
$28-37$ & 37 & Entrapped biomass & 33 & Isaka et al. (2008) \\
$20-43$ & - & Aggregated biomass & 70 & Strous et al. (1999) \\
$-2-13$ & 12 & Marine sediment & 51 & Rysgaard et al. (2004) \\
$10-20$ & - & Granule sludge & 72 & Hendrickx et al. (2012) \\
$10-40$ & $35-40$ & Bio-film biomass & 63 & Dosta et al. (2008) \\
$10-40$ & $35-40$ & Granular sludge & 63 & Dosta et al. (2008) \\
$6.5-37$ & 15 & Marine sediments & 61 & Dalsgaard and Thamdrup (2002) \\
$15-35$ & $>35$ & Granular sludge & 43 & Jin et al. (2013) \\
$5-30$ & 25 & Marine sediments & 54.6 & Kawagoshi et al. (2012) \\
$15-30$ & - & Granular sludge & 83.1 & Lotti et al. (2015) \\
$15-30$ & - & Free-cell suspension & 83.1 & Lotti et al. (2015) \\
$9-25$ & - & Granular sludge & 54.9 & Xing et al. (2015) \\
$5-17$ & $20-30$ & Activated sludge & 66 & Hendrickx et al. (2014) \\
$15-25$ & $35-40$ & Granular sludge & 95.9 & This study \\
$25-35$ & $35-40$ & Granular sludge & 43.2 & This study \\
$15-35$ & $35-40$ & Granular sludge & 69.5 & This study \\
\hline & & & &
\end{tabular}

The comparison of $\mathrm{E}_{\mathrm{a}}$ in different studies is shown in Table 2. $\mathrm{E}_{\mathrm{a}}$ acquired in this work was 95.9 and $69.5 \mathrm{~kJ} / \mathrm{mol}$ at $15-25$ and $25-35^{\circ} \mathrm{C}$, respectively. The result was not consistent with previous reports. Lotti et al. (2015) reported that the average $E_{a}$ value for granular anammox biomass was $83.1 \mathrm{~kJ} / \mathrm{mol}$ at
15-30 ${ }^{\circ} \mathrm{C}$. Jin et al. (2013) analyzed granular biomass at $15-35^{\circ} \mathrm{C}$, and the value of $\mathrm{E}_{\mathrm{a}}$ obtained was $43 \mathrm{~kJ} / \mathrm{mol}$. Besides, $\mathrm{E}_{\mathrm{a}}$ of marine AAOB was generally smaller than that of fresh ones. In addition, the immobilized or freecell biomass and the type of microorganisms were also important factors which affected $E_{a}$. 
Kinetic analysis

The Arrhenius model was used most widely to simulate temperature effect on anammox activity and AAOB growth (Jin et al. 2013; Lotti et al. 2015; Xing et al. 2015). However, it could not model the effect of temperature which was higher than optimal one (presented in Fig. 6) (Wang and Wan 2009). The Hinshelwood model which was based on the Arrhenius model was put forward to solve this problem and it reached good simulation result $\left(\mathrm{R}^{2}=0.9897\right.$ ) (data not shown). However, the parameters in equation were strongly correlated with each other and were very difficult to estimate. This aspect limited its further application. Besides, the simulated activation energies were unrealistic (Zwietering et al. 1991) and had little benefit to engineering application. As a result, it was not analyzed in this work.

The simulation of Ratkowsky model is presented in Fig. 8a. High correlation coefficient $\left(\mathrm{R}^{2}=0.9949\right)$ indicated that the Ratkowsky model was able to simulate SAA under different temperatures. In addition, the values of $\mathrm{T}_{\min }$ and $\mathrm{T}_{\max }$ were $7.8^{\circ} \mathrm{C}$ and $51.14{ }^{\circ} \mathrm{C}$ (shown in Table 3), respectively, which suggested anammox reaction in present research only occurred at $7.8-51.14{ }^{\circ} \mathrm{C}$. However, experimental result showed that AAOB had no activity at $10{ }^{\circ} \mathrm{C}$ in this work. This was not consistent with simulated value. The Zwietering model appeared to fit the data very well $\left(\mathrm{R}^{2}=0.9886\right)$ (shown in Fig. $8 \mathrm{~b}$ ) and the simulated results indicated that $\mathrm{T}_{\min }$ and $\mathrm{T}_{\max }$ were 10.21 and $50.13{ }^{\circ} \mathrm{C}$, respectively. The predicted
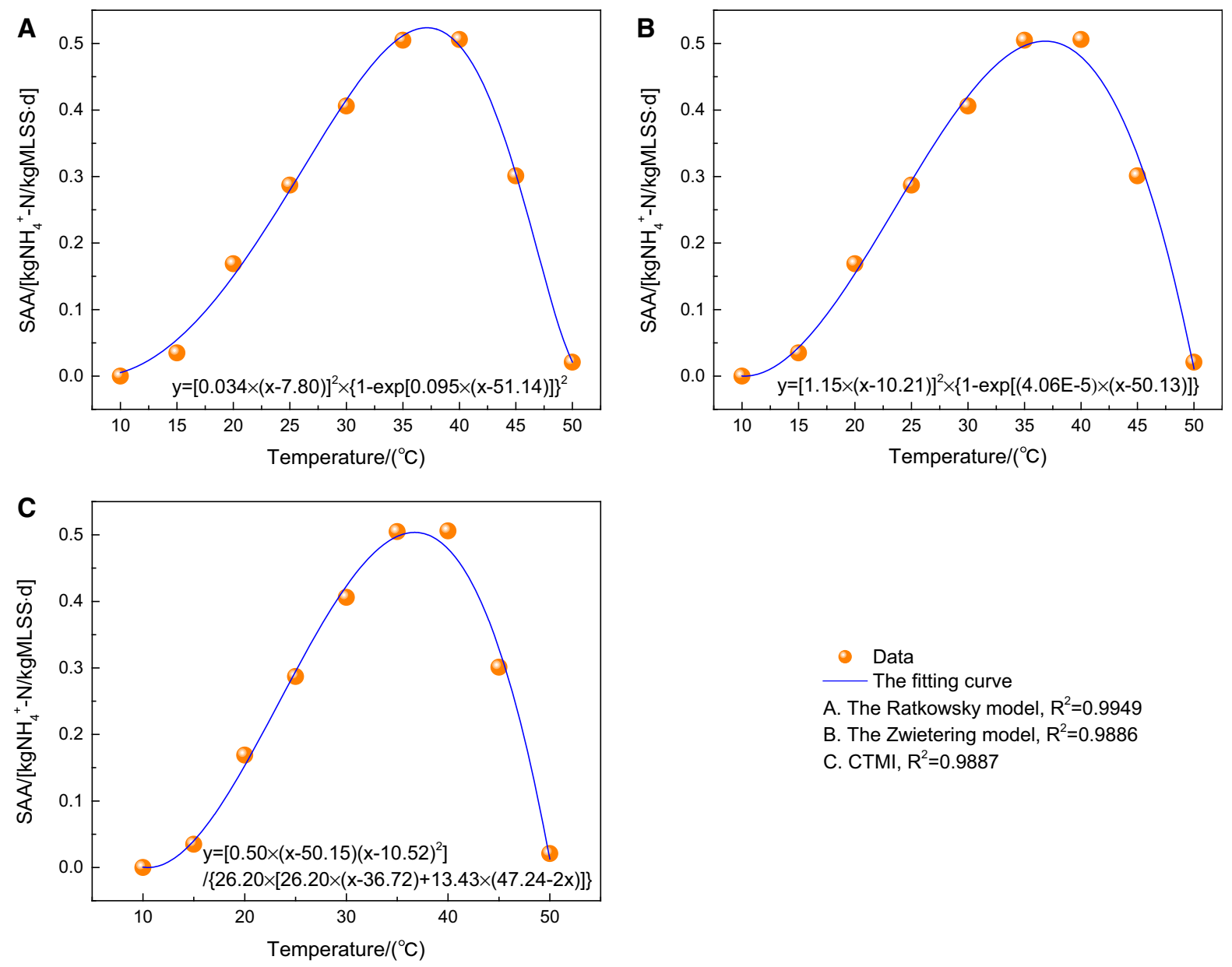

- Data The fitting curve

A. The Ratkowsky model, $R^{2}=0.9949$

B. The Zwietering model, $R^{2}=0.9886$

C. CTMI, $R^{2}=0.9887$

Fig. 8 The simulation of three models: a the Ratkowsky model; b the Zwietering model; c CITM 
Table 3 Simulated parameters of three kinetic models

\begin{tabular}{llllllll}
\hline Model & Parameter & \multicolumn{1}{l}{} & $\mathrm{R}^{2}$ \\
\cline { 2 - 6 } & $\mathrm{T}_{\min }\left({ }^{\circ} \mathrm{C}\right)$ & $\mathrm{T}_{\max }\left({ }^{\circ} \mathrm{C}\right)$ & $\mathrm{T}_{\text {opt }}\left({ }^{\circ} \mathrm{C}\right)$ & $\mathrm{A}$ & $\mathrm{B}$ & $\mu_{\max } /\left[\mathrm{kgNH}_{4}{ }^{+}-\mathrm{N} /(\mathrm{kgMLSS} \cdot \mathrm{d})\right]$ & \\
\hline Ratkowsky model & 7.80 & 51.14 & - & 0.03 & 0.09 & - & 0.9949 \\
Zwietering model & 10.21 & 50.13 & - & 1.15 & 4.06 & - & 0.9886 \\
CTMI & 10.52 & 50.15 & 36.72 & - & - & 0.50 & 0.9887 \\
\hline
\end{tabular}

values were in good agreement with experimental data. Similar with Ratkowsky model, only two practical parameters were fitted by Zwietering model. As a result, the cardinal temperature model with inflection (CTMI) was used in anammox process. It was first used in the analysis of anammox process.

As presented in Fig. 8c, CTMI had high correlation coefficient $\left(\mathrm{R}^{2}=0.9887\right)$ which indicated it was able to simulate SAA with temperature shock. Compared to the two models described above, CTMI could simulate $\mathrm{T}_{\text {opt }}$ and $\mu_{\max }$. For the experimental data, anammox process could occur within $10-50{ }^{\circ} \mathrm{C}$ with maximum SAA at $35-40{ }^{\circ} \mathrm{C}$. According to the simulation of CTMI, anammox reaction could occur at $10.52-50.15^{\circ} \mathrm{C}$ with maximum SAA of $0.50 \mathrm{~kg} /$ (kg day) at $36.72{ }^{\circ} \mathrm{C}$ (shown in Table 3 ). The value of simulated parameters (e.g., $\mathrm{T}_{\min }, \mathrm{T}_{\max }, \mathrm{T}_{\text {opt }}$ and $\left.\mu_{\max }\right)$ were similar with experimental data. This was beneficial to engineering application of anammox process. In conclusion, CTMI could describe temperature effect on anammox activity throughout the entire bio-kinetic temperature range precisely.

The speculative mechanisms resulting temperature effect on anammox process were as follows. Firstly, as thermophilic bacteria, temperature was an important factor to some essential enzyme in cell (Wang and Wan 2009; Xing et al. 2015). The enzyme-catalyzed rate was affected greatly at low or high temperature which resulted in the inhibition of anammox process. Secondly, the fluidity of cytoplasm and cell membrane were also affected by temperature, as well as liquidity of cytoplasm and mass transfer rate (Jin et al. 2013; Xing et al. 2015). Protein was the carrier in cell membrane. It would denaturate at high temperature and lose activity at low temperature. Both affected trans-membrane transport and worsened nitrogen removal performance. Thirdly, nitrite was accumulated in anammox reactor at extreme temperature. As nitrite was inhibitory for $\mathrm{AAOB}$, even at moderate concentrations (Jung et al. 2007; Strous et al. 1999), it could cause a decrease of anammox activity. Fourthly, anammox process was also affected by free ammonia (FA) and free nitrous acid (FNA) at extreme temperature (Anthonisen et al. 1976). A temperature rise increased FA concentration, which had been reported to inhibit anammox activity at $1.7-8.3 \mathrm{mg} / \mathrm{L}$ (Jaroszynski et al. 2011; Jung et al. 2007). In addition, a decrease in substrate affinity under low temperature could also result in poor anammox performance (Guo et al. 2015).

Operation strategy under low temperature

\section{Acclimatization to low temperature}

As presented in Fig. 2c, TNRR increased from $0.02 \pm 0.01$ to $0.072 \pm 0.01 \mathrm{~kg} /\left(\mathrm{m}^{3}\right.$ day $)$ after 50 cycles' operation at $15^{\circ} \mathrm{C}$. This indicated that the activity of AAOB could be enhanced with cold acclimatization. In view of slow growth rate of AAOB (Strous et al. 1999), the acclimatization duration should be long enough.

In order to explore cold acclimatization, R2 was continuously operated at $15{ }^{\circ} \mathrm{C}$. TNRR increased to around $0.2 \mathrm{~kg} /\left(\mathrm{m}^{3}\right.$ day) with another 50 cycles' operation. It restored to about $30 \%$ of TNRR at $35^{\circ} \mathrm{C}$ (data not shown). Anammox biomass could progressively adapt to low temperature. Hu et al. (2013) found the optimum temperature for AAOB decreased from 35 to $25{ }^{\circ} \mathrm{C}$ after long-term cultivation at $12{ }^{\circ} \mathrm{C}$. Similar result was acquired by Dosta et al. (2008). Acclimatization at low temperature depended on duration time and longer acclimatization period was needed at lower temperature. Therefore, low temperature could result in the enrichment of other anammox bacteria which had a lower optimum temperature (Hendrickx et al. 2012).

Ma et al. (2013) obtained a high TNRR of $2.28 \mathrm{~kg} /$ $\left(\mathrm{m}^{3}\right.$ day) in an anammox reactor at $16^{\circ} \mathrm{C}$, which was 
much higher than the present work. Sludge concentration might also result in the discrepancy. Even though a much higher biomass concentration was required to treat wastewater at low temperature (Hendrickx et al. 2014), it was also meaningful to study the acclimatization of anammox bacteria to low temperature. Due to the low growth rate of anammox bacteria, it needed a long time to start-up anammox system and the sludge concentration usually was low at the beginning. Adding sludge into reactor was an effective method to enhance nitrogen removal performance at low temperature (Yang and Jin 2013; Jin et al. 2013).

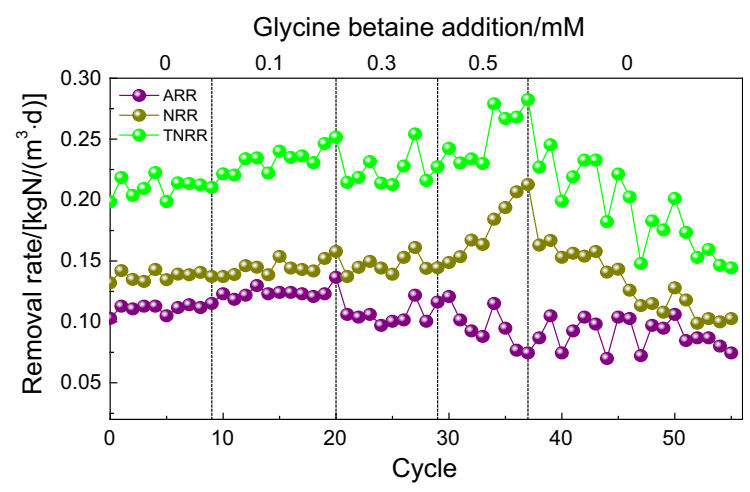

Fig. 9 Nitrogen removal performance with glycine betaine addition at low temperature
Addition of glycine betaine

In order to explore glycine betaine effect on anammox at low temperature, R3 was continuously operated at $20{ }^{\circ} \mathrm{C}$. As presented in Fig. 9, when glycine betaine dose was $0.10 \mathrm{mM}$, ARR was $0.121 \pm 0.008 \mathrm{~kg} /$ $\left(\mathrm{m}^{3}\right.$ day), slightly higher than that without glycine betaine addition. NRR and TNRR were also slightly improved. When glycine betaine dose was $0.5 \mathrm{mM}$, ARR decreased to $0.095 \pm 0.02 \mathrm{~kg} /\left(\mathrm{m}^{3}\right.$ day). However, NRR and TNRR increased to $0.198 \pm 0.015$ and $0.274 \pm 0.008 \mathrm{~kg} /\left(\mathrm{m}^{3}\right.$ day $)$, respectively. As a kind of organic matter, glycine betaine could promote the growth of heterotrophic denitrifying bacteria. Glycine betaine addition could slightly promote anammox activity at low temperature. However, as a small molecular organic matter accumulated in bacteria, it might lead to denitrification in reactor at high concentration. As a result, intermittent addition of glycine betaine might be more suitable for anammox process than continuous addition.

The slight enhancement of anammox performance could be attributed to the role of glycine betaine in maintaining membrane fluidity at low temperature and the ability to prevent cold-induced aggregation of cellular proteins (Chattopadhyay 2002; Jones et al. 2002). In this way, glycine betaine increased the permeability of cell membrane. Chattopadhyay (2002) found that inductive synthesis of some heat shock

Table 4 Comparison of different operation strategies at low temperature

\begin{tabular}{lllll}
\hline Method & Temperature $\left({ }^{\circ} \mathrm{C}\right)$ & Description $^{\mathrm{a}}$ & Effect & Reference \\
\hline $\mathrm{pH}$ & 15 & $\mathrm{pH} 6.5 \rightarrow 7.5$ & SAA 0 $\rightarrow 0.0025^{\mathrm{b}}$ & Daverey et al. (2015) \\
$\mathrm{pH}$ & 15 & $\mathrm{pH} 6.5 \rightarrow 8.0$ & Doubled SAA & Daverey et al. (2015) \\
Ultrasound irradiation & 15 & low-strength & $258 \%$ more NRR & Yu et al. (2013) \\
HRT & $20-22$ & shorter HRT & higher TNRR & Isaka et al. (2007) \\
Extra calcium & 25 & addition & higher TNRR & de Graaff et al. (2011) \\
Polymeric matrix & - & addition & cold tolerance enhancement & Heylen et al. (2012) \\
Biomass & 9.1 & addition & Jin et al. (2013) \\
Biomass acclimatization & 12 & 120 days operation & SAA 12 $\rightarrow 18^{\text {d }}$ & Hu et al. (2013) \\
Glycine betaine addition & $9.2 \pm 0.5$ & 0.15 mM & effective & Jin et al. (2013) \\
Biomass acclimatization & 15 & $>50$ days operation & effective & This study \\
Glycine betaine addition & 20 & $0.1 \mathrm{mM}$ & effective & This study
\end{tabular}

a Description of method in detail

b $\mathrm{kgNH}_{4}{ }^{+}-\mathrm{N} /(\mathrm{kgMLSS}$ day)

c Added $10 \mathrm{~mL}$ sludge every other day

d $\mathrm{nmol} \mathrm{N} /(\mathrm{mg}$ total protein $\mathrm{min})$ 
proteins (HSPs) was remarkably increased. In addition, glycine betaine helped to maintain membrane fluidity by promoting synthesis of specific fatty acids at low temperature (Chattopadhyay 2002; Jones et al. 2002). Still, previous studies reported that low concentration of organic matter could promote anammox performance (van de Graaf et al. 1996; Güven et al. 2005). As a result, anammox performance was improved upon glycine betaine addition. Jin et al. (2013) demonstrated that glycine betaine addition was a strategy to improve bioprocess performance at $10{ }^{\circ} \mathrm{C}$. However, glycine betaine might increase anammox activity transiently just as reported in the previous study on anaerobic biomass (Vyrides et al. 2010). The contact time and feed mode might also affect process performance and further study was needed.

Compared with other enhancing strategies listed in Table 4, ultrasound irradiation, addition of extra calcium and polymeric matrix, biomass addition were all effective to strengthen anammox performance. Among them, intermittent ultrasound could enhance bio-activity with a short time through accelerating substance exchange and membrane permeability (Xie et al. 2009). However, continuous exposure should be avoided because cell structure would be destroyed. Therefore, it is important to evaluate different strategies and achieves efficient and stable nitrogen removal at low temperature.

\section{Conclusions}

Both long-term and short-term temperature effects on anammox process were studied in this work. Nitrogen removal performance worsened when temperature was lower than $25^{\circ} \mathrm{C}$. Besides, low temperature reduced settling velocity of biomass although the morphology of bacteria was not modified. In batch test, $\mathrm{E}_{\mathrm{a}}$ decreased with dropping temperature. The inhibition resulting from low temperature could be relieved through cold acclimatization of bacteria. In addition, the addition of glycine betaine could slightly improve nitrogen removal performance. CTMI could describe temperature effect on anammox activity throughout the entire bio-kinetic temperature range precisely. The simulated results revealed that anammox reaction could occur at $10.52-50.15{ }^{\circ} \mathrm{C}$ with maximum SAA of $0.50 \mathrm{~kg} /(\mathrm{kg}$ day $)$ at $36.72{ }^{\circ} \mathrm{C}$.
Acknowledgements The work was financially supported by National Natural Scientific Foundation (41376016), Shandong Provincial Natural Science Foundation (BS2015HZ007), Shandong Province Higher Educational Science and Technology Program (J15LC61) and Qingdao Municipal Applied Fundamental Research Program (13-1-4-203-jch). The authors also would like to thank the editor and anonymous reviewers for their editing and review.

\section{References}

Anthonisen AC, Loehr RC, Prakasam TB, Srinath EG (1976) Inhibition of nitrification by ammonia and nitrous acid. Water Pollut Control Fed 48(5):835-852

APHA (1998) Standard methods for water and wastewater examination. American Public Health Association, Washington (DC)

Brown AD (1976) Microbial water stress. Bacteriol Rev 40(4):803-846

Byrne N, Strous M, Crépeau V, Kartal B, Birrien JL, Schmid M, Lesongeur F, Schouten S, Jaeschke A, Jetten M, Prieur D, Godfroy A (2009) Presence and activity of anaerobic ammonium-oxidizing bacteria at deep-sea hydrothermal vents. ISME J 3(1):117-123

Chattopadhyay MK (2002) The cryoprotective effects of glycine betaine on bacteria. Trends Microbiol 10(7):311

Cleland D, Krader P, McCree C, Tang J, Emerson D (2004) Glycine betaine as a cryoprotectant for prokaryotes. J Microbiol Methods 58(1):31-38

Dalsgaard T, Thamdrup B (2002) Factors controlling anaerobic ammonium oxidation with nitrite in marine sediments. Appl Environ Microb 68(8):3802-3808

Daverey A, Chei PC, Dutta K, Lin JG (2015) Statistical analysis to evaluate the effects of temperature and $\mathrm{pH}$ onanammox activity. Int Biodeterior Biodegr 102:89-93

de Costa MS, Santos H, Galinski EA (1998) An overview of the role and diversity of compatible solutes in Bacteria and Archaea. Adv Biochem Eng Biotechnol 61:117-153

de Graaff MS, Temmink H, Zeeman G, van Loosdrecht MCM, Buisman CJN (2011) Autotrophic nitrogen removal from black water: calcium addition as a requirement for settleability. Water Res 45(1):63-74

Dosta J, Fernández I, Vázquez-Padín JR, Mosquera-Corral A, Campos JL, Mata-Álvarez J, Méndez R (2008) Short- and long-term effects of temperature on the Anammox process. J Hazard Mater 154(1):688-693

Du R, Cao S, Wang S, Niu M, Peng Y (2016) Performance of partial denitrification (PD)-ANAMMOX process in simultaneously treating nitrate and low $\mathrm{C} / \mathrm{N}$ domestic wastewater at low temperature. Bioresour Technol 219:420-429

Egli K, Fanger U, Alvarez PJJ, Siegrist H, van de Meer JR, Zehnder AJB (2001) Enrichment and characterization of an anammox bacterium from a rotating biological contactor treating ammonium-rich leachate. Arch Microbiol 175(3):198-207

Guo Q, Xing BS, Li P, Xu JL, Yang CC, Jin RC (2015) Anaerobic ammonium oxidation (anammox) under realistic seasonal temperature variations: characteristics of 
biogranules and process performance. Bioresour Technol 192:765-773

Güven D, Dapena A, Kartal B, Schmid MC, Maas B, van de PasSchoonen K, Sozen S, Mendez R, Op den Camp HJM, Jetten MSM, Strous M, Schmidt I (2005) Propionate oxidation by and methanol inhibition of anaerobic ammonium-oxidizing bacteria. Appl Environ Microbiol 71(2):1066-1071

Hendrickx TLG, Wang Y, Kampman C, Zeeman G, Temmink $\mathrm{H}$, Buisman CJN (2012) Autotrophic nitrogen removal from low strength waste water at low temperature. Water Res 46(7):2187-2193

Hendrickx TLG, Kampman C, Zeeman G, Temmink H, Hu Z, Kartal B, Buisman CJN (2014) High specific activity for anammox bacteria enriched from activated sludge at $10^{\circ} \mathrm{C}$. Bioresour Technol 163:214-221

Heylen K, Ettwig K, Hu Z, Jetten M, Kartal B (2012) Rapid and simple cryopreservation of anaerobic ammonium-oxidizing bacteria. Appl Environ Microbiol 78(8):3010-3013

Hu Z, Lotti T, de Kreuk M, Kleerebezem R, van Loosdrecht M, Kruit J, Jetten MSM, Kartal B (2013) Nitrogen removal by a nitritation-anammox bioreactor at low temperature. Appl Environ Microbiol 79(8):2807-2812

Isaka K, Sumino T, Tsuneda S (2007) High nitrogen removal performance at moderately low temperature utilizing anaerobic ammonium oxidation reactions. J Biosci Bioeng 103(5):486-490

Isaka K, Date Y, Kimura Y, Sumino T, Tsuneda S (2008) Nitrogen removal performance using anaerobic ammonium oxidation at low temperatures. FEMS Microbiol Lett 282(1):32-38

Jaroszynski LW, Cicek N, Sparling R, Oleszkiewicz JA (2011) Importance of the operating $\mathrm{pH}$ in maintaining the stability of anoxic ammonium oxidation (anammox) activity in moving bed biofilm reactors. Bioresour Technol 102(14):7051-7056

Jetten MSM, Strous M, van de Pas-Schoonen KT, Schalk J, van Dongen UGJM, van de Graaf AA, Logemann S, Muyzer G, van Loosdrecht MCM, Kuenen JG (1998) The anaerobic oxidation of ammonium. FEMS Microbiol Rev 22(5):421-437

Jin RC, Ma C, Yu JJ (2013) Performance of an Anammox UASB reactor at high load and low ambient temperature. Chem Eng J 232(10):17-25

Jones SL, Drouin P, Wilkinson BJ, Morse PD II (2002) Correlation of long-range membrane order with temperaturedependent growth characteristics of parent and a coldsensitive, branched-chain-fatty-acid-deficient mutant of Listeria monocytogenes. Arch Microbiol 177(3):217-222

Jung JY, Kang SH, Chung YC, Ahn DH (2007) Factors affecting the activity of anammox bacteria during start up in the continuous culture reactor. Water Sci Technol 55(1-2):459-468

Kartal B, Kuypers MMM, Lavik G, Schalk J, Op den Camp HJM, Jetten MSM, Strous M (2007) Anammox bacteria disguised as denitrifiers: nitrate reduction to dinitrogen gas via nitrite and ammonium. Environ Microbiol 9(3):635-642

Kartal B, Kuenen JG, van Loosdrecht MCM (2010) Sewage treatment with anammox. Science 328(5976):702-703
Kawagoshi Y, Fujisaki K, Tomoshige Y, Yamashiro K, Qiao Y (2012) Temperature effect on nitrogen removal performance and bacterial community in culture of marine anammox bacteria derived from sea-based waste disposal site. J Biosci Bioeng 113(4):515-520

Lotti T, Kleerebezem R, Hu Z, Kartal B, Jetten MSM, van Loosdrecht MCM (2014a) Simultaneous partial nitritation and anammox at low temperature with granular sludge. Water Res 66:111-121

Lotti T, Kleerebezem R, van Erp Taalman Kip C, Hendrickx TLG, Kruit J, Hoekstra M, van Loosdrecht MCM (2014b) Anammox growth on pretreated municipal wastewater. Environ Sci Technol 48(14):7874-7880

Lotti T, Kleerebezem R, van Loosdrecht MCM (2015) Effect of temperature change on anammox activity. Biotechnol Bioeng 112(1):98-103

Ma B, Peng Y, Zhang S, Wang J, Gan Y, Chang J, Wang S, Wang S, Zhu G (2013) Performance of anammox UASB reactor treating low strength wastewater under moderate and low temperatures. Bioresour Technol 129:606-611

Mu Y, Ren TT, Yu HQ (2008) Drag coefficient of porous and permeable microbial granules. Environ Sci Technol 42(5):1718-1723

Qiao S, Yin X, Zhou J, Furukawa K (2014) Inhibition and recovery of continuous electric field application on the activity of anammox biomass. Biodegradation 25(4):505-513

Quan LM, Khanh DP, Hira D, Fujii T, Furukawa K (2011) Reject water treatment by improvement of whole cell anammox entrapment using polyvinyl alcohol/alginate gel. Biodegradation 22(6):1155-1167

Ratkowsky DA, Olley J, McMeekin TA, Ball A (1982) Relationship between temperature and growth rate of bacterial cultures. J Bacteriol 149(1):1-5

Rosso L, Lobry JR, Flandrois JP (1993) An unexpected correlation between cardinal temperatures of microbial growth highlighted by a new model. J Theor Biol 162(4):447-463

Rysgaard S, Glud RN, Risgaard-Petersen N, Dalsgaard T (2004) Denitrification and anammox activity in Arctic marine sediments. Limnol Oceanogr 49(5):1493-1502

Schleper C (2008) Microbial ecology: metabolism of the deep. Nature 456(7223):712-714

Strous M, Heijnen JJ, Kuenen JG, Jetten MSM (1998) The sequencing batch reactor as a powerful tool for the study of slowly growing anaerobic ammonium-oxidizing microorganisms. Appl Microbiol Biotechnol 50(5):589-596

Strous M, Kuenen JG, Jetten MSM (1999) Key physiology of anaerobic ammonium oxidation. Appl Environ Microbiol 65(7):3248-3250

Tang CJ, Zheng P, Wang CH, Mahmood Q, Zhang JQ, Chen XG, Zhang L, Chen JW (2011) Performance of high-loaded ANAMMOX UASB reactors containing granular sludge. Water Res 45(1):135-144

van de Graaf AA, de Bruijn P, Robertson LA, Jetten MSM, Kuenen JG (1996) Autotrophic growth of anaerobic ammonium-oxidizing microorganisms in a fluidized bed reactor. Microbiology 142(8):2187-2196

van der Star WRL, Abma WR, Blommers D, Mulder JW, Tokutomi T, Strous M, Picioreanu C, van Loosdrecht MCM (2007) Startup of reactors for anoxic ammonium 
oxidation: experiences from the first full-scale Anammox reactor in Rotterdam. Water Res 41(18):4149-4163

Vyrides I, Stuckey DC (2009) Adaptation of anaerobic biomass to saline conditions: role of compatible solutes and extracellular polysaccharides. Enzym Microb Technol 44(1):46-51

Vyrides I, Santos H, Mingote A, Ray MJ, Stuckey DC (2010) Are compatible solutes compatible with biological treatment of saline wastewater? Batch and continuous studies using submerged anaerobic membrane bioreactors (SAMBRs). Environ Sci Technol 44(19):7437-7442

Wang J, Wan W (2009) Kinetic models for fermentative hydrogen production: a review. Int J Hydrogen Energy 34(8):3313-3323

Winkler MKH, Bassin JP, Kleerebezem R, van der Lans RGJM, van Loosdrecht MCM (2012) Temperature and salt effects on settling velocity in granular sludge technology. Water Res 46(16):5445-5451

Xie B, Hong L, Yan Y (2009) Improvement of the activity of anaerobic sludge by low-intensity ultrasound. J Environ Manag 90(1):260-264
Xing BS, Guo Q, Yang GF, Zhang J, Qin TY, Li P, Ni WM, Jin RC (2015) The influences of temperature, salt and calcium concentration on the performance of anaerobic ammonium oxidation (anammox) process. Chem Eng J 265:58-66

Yang GF, Jin RC (2013) Reactivation of effluent granular sludge from a high-rate Anammox reactor after storage. Biodegradation 24(1):13-32

Yu JJ, Hui C, Zhang J, Ji YX, Liu QZ, Jin RC (2013) Enhancement of ANAMMOX activity by low-intensity ultrasound irradiation at ambient temperature. Bioresour Technol 142:693-696

Zhang Y, Niu Q, Ma H, He S, Kubota K, Li YY (2016) Longterm operation performance and variation of substrate tolerance ability in an anammox attached film expanded bed (AAFEB) reactor. Bioresour Technol 211:31-40

Zwietering MH, de Koos JT, Hasenack BE, de Witt JC, van 't Riet K (1991) Modeling of bacterial growth as a function of temperature. Appl Environ Microbiol 57(4):1094-1101 